\title{
Entrepreneurial Alliances as Contractual Forms
}

\author{
Jeffrey J. Reuer \\ Kenan-Flagler Business School \\ University of North Carolina \\ McColl Building, CB\#3490 \\ Chapel Hill, NC 27599 \\ Tel.: (919) 962-4514 \\ Fax: (919) 962-4266 \\ E-mail: reuer@unc.edu \\ Africa Ariño \\ IESE Business School \\ Av. Pearson 21 \\ 08034 Barcelona, Spain \\ Tel.: (34) 932534200 \\ Fax: (34) 932534343 \\ E-mail: afarino@iese.edu \\ Thomas Mellewigt \\ University of Leipzig \\ Faculty of Business and Economics \\ 04109 Leipzig, Germany \\ Tel: (49) 341-9733881 \\ Fax: (49) 341-9733889 \\ E-mail: mellewigt@ wifa.uni-leipzig.de
}

June 2004

Keywords: entrepreneurial alliances; alliance contracts; alliance design; contract negotiations; telecommunications industry 


\title{
Entrepreneurial Alliances as Contractual Forms
}

\begin{abstract}
Advancing upon taxonomical research on interfirm alliances, we investigate the design of entrepreneurial firms' alliances in more fine-grained terms by focusing on the specific contractual provisions that firms negotiate into their alliance contracts. Drawing upon transaction cost arguments, we examine the determinants of the contractual complexity of collaborative agreements in the German telecommunications industry. The findings reveal that alliance contracts vary greatly in their complexity, yet contracts for non-equity alliances tend to be no more or less complex than those for equity alliances on average, which challenges the view that the latter unambiguously afford firms greater control than the former. Furthermore, multivariate findings on the roles of transaction-specific investment, relational capital, search costs, and so forth demonstrate that firms' contractual and governance choices have distinct antecedents.
\end{abstract}




\section{Entrepreneurial Alliances as Contractual Forms}

\section{Executive Summary}

Inter-firm alliances offer benefits as well as pose challenges for entrepreneurial firms. For the potential benefits to be achieved, entrepreneurs have to pay attention both to the initial conditions that surround the exchange and to the processes by which they manage the alliance. Beyond contingencies such as partners' demographic and institutional characteristics or their prior experiences with each other, initial conditions include the way the alliance is structured, including alliance design characteristics such as the content of the contract or the alliance governance form. Alliance management processes involve pre-agreement activities such as partner selection and alliance negotiation, as well as post-agreement practices such as alliance evaluation and re-negotiation processes.

Despite the importance of initial conditions and managerial processes, not all of them have received enough research attention. Substantial research has been devoted to issues related to the partners' identities and prior relations, and on the decision to structure the alliance as an equity or non-equity agreement. However, very little is known about the contents of alliance contracts, particularly in the entrepreneurship area. Further, it is often assumed that alliance contract design goes hand in hand with the choice of alliance governance structure, and that equity alliances necessarily involve greater complexity than non-equity agreements. However, entrepreneurial firms have greater degrees of freedom than depicted in prior studies of alliance governance. 
This study examines the contractual design of alliances of entrepreneurial firms. After exploring the incidence of particular contractual provisions in alliances, we draw from transaction cost theory to examine some of the determinants of contractual complexity. In addition, we investigate whether or not these antecedents determine the choice of alliance governance form in a similar fashion The study investigates a sample of alliances of entrepreneurial firms in the German telecommunications industry. A survey was administered to these firms to examine their alliances, and in particular the contents of the alliances' contracts. These contracts tended to be fairly complex on average relative to other collaborative agreements and, with few exceptions, there were no significant differences in the use of specific contractual provisions across equity and non-equity alliances.

The evidence reveals that entrepreneurial firms tend to design more complex contracts the higher the costs of searching for a partner, and the higher the strategic importance they assign to the alliance. Asset specificity leads to the choice of an equity alliance over a non-equity arrangement, but does not influence the contractual complexity of an alliance. In a similar fashion, we find that relational capital among alliance partners is associated with nonequity rather than equity alliances, but the extent of relational capital between partners does not differ systematically across alliances of varying contractual complexity. Perhaps due to the high level of environmental uncertainty in the telecommunications industry, firms appear to turn to a governance solution rather than a more incremental contractual solution when faced with the risks surrounding transaction-specific investment or the lack of relational capital. By contrast, firms design more complex contracts for strategically important alliances, but this factor does not shape the use of equity alliances over non-equity collaborations. 
On a general level, the evidence therefore underscores the fact that governance structures and contractual forms have different antecedents for entrepreneurial firms. Overall, the findings suggest that entrepreneurial firms consider both the costs of contract negotiation and renegotiation. They tend to negotiate more complex contracts when the expected negotiation costs exceed the potential losses from contractual non-compliance. They also consider renegotiation costs, turning to governance solutions in order to avoid likely and costly contractual renegotiations in the face of transaction-specific investments. 


\section{INTRODUCTION}

In recent years, growing research attention has been given to entrepreneurial firms and the roles that alliances can play in these firms' developmental processes and the creation of wealth (e.g., Park \& Kim, 1997; Zahra, Ireland, \& Hitt, 2000; Sarkar, Echambadi, \& Harrison, 2001). This new body of research has identified a number of important determinants of entrepreneurial firms' decisions to enter into alliances (e.g., Egelhoff \& Haklisch, 1994; Dickson \& Weaver, 1997; Steensma, Marino, Weaver, \& Dickson, 2000; Marino, Strandholm, Steensma, $\&$ Weaver, 2002). This work has also begun to study the benefits and potential challenges that entrepreneurs experience when engaging in interfirm collaboration (e.g., Weaver \& Dickson, 1998; Coombs \& Deeds, 2000; George, Zahra, \& Wood, 2002). Given the importance of the phenomenon of interfirm collaboration in the realm of entrepreneurship in recent years as well as the underlying theoretical differences that exist across entrepreneurial firms and established firms (e.g., Acs \& Audretsch, 1987; Covin \& Slevin, 1991; Shane, 1994; Shane \& Venkataraman, 2000) that have been the focus of some of the theorizing about alliances, there are many other important unanswered questions concerning how entrepreneurial firms might invest in and manage alliances.

In this paper, we present an empirical analysis of the contractual design of entrepreneurial alliances, or collaborative agreements entered into by an entrepreneurial firm. The paper offers three contributions to the literature. First, by examining contracts for entrepreneurial alliances, this study advances beyond the extensive research on organizational governance that has been conducted on related questions such as whether a firm should invest in an alliance or when particular types of alliances such as equity or non-equity arrangements are appropriate in hightech settings (e.g., Pisano, 1989). Very little research, however, has been devoted to the specifics 
of alliance negotiation and the role of contract design in particular, either in general or in the entrepreneurship setting (e.g., Parkhe, 1993; Deeds \& Hill, 1996; Lerner \& Merges, 1998). Relative to these broader decisions concerning alliance investment and governance structures, the contractual view of alliances developed in this paper suggests that entrepreneurial firms have much more latitude in allocating and specifying obligations, rewards and risks, procedures, and so forth through individual contractual provisions that they put into their collaborative agreements. Our interest therefore lies in moving beyond such broad taxonomies and digging into the details of alliance design by investigating the incidence of various contractual provisions in alliances. We then turn out attention to the antecedents of the provisions used by entrepreneurial firms forming strategic alliances. In our research, we have collected and examined primary data on entrepreneurial firms' usage of eight different types of contractual provisions in collaborative agreements. These provisions appearing in alliance contracts range from notification and auditing rights to obligations concerning proprietary information to more stringent clauses concerning dispute resolution and alliance termination.

Second, we theoretically and empirically distinguish firms' contractual decisions from their broader governance structure decisions in designing strategic alliances. For instance, alliance control is also more complicated than the equity/non-equity dichotomy allows since numerous controls can be built into non-equity alliances, even if the controls stemming from shared ownership and joint boards found in equity agreements are lacking. It is therefore not adequate to subsume this contractual heterogeneity under broader governance categorizations such as equity versus non-equity, assuming a one-to-one relationship between governance and contract and that control is related to governance in a simple, direct fashion (James, 2000). Our empirical results show, in fact, that non-equity alliance contracts are no more or less complex 
than contracts for equity alliances, which questions the view that equity alliances necessarily afford firms greater control that non-equity arrangements. The findings also demonstrate that contractual provisions and governance structures have different antecedents, which suggests that the former should not be subsumed within the latter.

Finally, from a practical perspective, a more fine-grained investigation into contractual terms in alliances may help collaborating firms devise remedies for foreseeable contingencies or design processes for unforeseeable outcomes. Given the risks encountered by entrepreneurial firms in alliances (e.g., Doz, 1988), such alliance design choices can take on importance in setting the stage for the subsequent evolution of the collaborative relationship and the benefits it ultimately brings, or fails to deliver, to the partners involved.

In the next section, we develop a set of hypotheses that identify potential determinants of entrepreneurial firms' usage of contractual provisions in alliances. We then provide an overview of our research design, offering details of a survey of entrepreneurial firms in the German telecommunications industry. After providing descriptive findings on the incidence of various contractual provisions in non-equity as well as equity alliances in this sector, we present the multivariate results on the factors shaping the complexity or simplicity of alliance contracts. We find that alliance contracts tend to be more complex when the entrepreneurial firm engaged in an extensive effort to locate an alliance partner and when the alliance is of strategic relevance to the firm. We also explore whether the factors hypothesized to influence contractual complexity have a similar impact on the governance form chosen. The results indicate that the determinants of contractual complexity in alliances differ from the determinants of governance structure. For instance, the strategic importance of the alliance influences contractual design but not governance structure, and the opposite holds true for asset specificity and relational capital. We 
conclude with a discussion of the implications of these findings and potential avenues for future research on entrepreneurial firms' alliance design alternatives.

\section{THEORY AND HYPOTHESES}

Typical economic treatments of alliances have relied upon transaction cost theory to examine the efficiency of alliances relative to other organizational forms such as acquisitions, internal development, and so forth. These analyses have examined a variety of contractual hazards and other conditions that influence a firm's decision to adopt an alliance over some other governance structure and therefore represent applications of transaction cost theory across governance structures. In the theoretical arguments presented below, we also apply these perspectives within a governance structure - strategic alliances in the case of this study - as is characteristic of related work on the economics of contracts. For instance, Joskow (1988) has assessed the effects of asset specificity on the length of supply contracts, and more recently Poppo and Zenger (2002) have examined contractual complexity in IT outsourcing contracts.

\section{Transaction-Specific Investments}

Standard applications of transaction cost reasoning to the alliance setting arrays various forms of alliances and other organizational forms along the governance continuum and discusses the combined risks of opportunistic behavior and governance costs for a given level of exchange hazards and a given type of organizational governance. The tradeoff is that the adoption of more extensive governance mechanisms mitigates the threat of opportunistic behavior, but at the expense of heightened governance costs.

This leads to the fundamental discriminating alignment tenet of transaction cost theory, which states that governance structures need to be aligned with exchange hazards in a 
discriminating fashion to balance the risks of opportunistic behavior and governance costs (Williamson, 1985, 1991). If "too much" governance is put in place, for instance if an equity arrangement is chosen for a comparatively simple transaction, then the firm unduly bears governance costs as a result of slowed decision making and excessive bureaucracy (Williamson, 1991). If "too little" governance is put in place, for instance if a non-equity arrangement is chosen when exchange hazards are high, then the firm risks exposure to those exchange hazards. While the principle of discriminating alignment is most commonly used across the discrete governanc e structures firms employ when expanding overseas or in product markets (e.g., Zacharakis, 1997), it also holds within governance structures. More specifically, the theory suggests that to the degree that exchange hazards are low, managers can avoid the costs of negotiating complicated contracts that detail potential contingencies, parties' responses to them, and a framework for resolving disputes. Conversely, the theory suggests that firms will only seek to bear such costs when the consequences of exchange hazards become significant. The costs of instituting safeguards into alliance contracts become worthwhile to bear when such safeguards act to reduce the costs and performance losses from exchange hazards (e.g., Macneil, 1978; Heide, 1994). In the alliance context, for instance, Parkhe (1993) reports that perceptions of opportunistic behavior lead firms to negotiate more contractual safeguards into their alliance contracts. Deeds and Hill (1999), however, do not find evidence that contractual deterrents affect firms' perceptions of opportunistic behavior in biotechnology alliances.

Prior research on contracts argues and finds that asset specificity is an important transactional attribute affecting contract design (e.g., Joskow, 1988). When firms make transaction-specific investments in an alliance, the partner can threaten to terminate the alliance, which would result in the firm giving up the value of specialized assets. Faced with such threats, 
managers must therefore weigh the value losses they would experience from hold-up behavior with the costs of negotiating safeguards into their alliance contracts ex ante. As the potential value loss due to transaction-specific investment increases, managers will find it beneficial to negotiate more complex contracts to cover the consequences of breach and termination as well as the processes by which such threats will be handled. For example, partners can specify rights of first refusal on a joint venture's shares, ownership on intellectual property, the means by which an alliance will be terminated, whether a partner buyout price is set ex ante or determined ex post by third party appraisal, and so forth. Firms can also spell out in the alliance contract the processes by which disputes will be resolved internally or adjudicated by third parties. We therefore predict:

\section{H1: $\quad$ The contractual complexity of an entrepreneurial alliance will be positively related to asset specificity.}

\section{Relational Capital}

The alliance literature has focused extensively on partner opportunism and the use of contractual agreements to address it (Kale et al., 2000). Gulati (1995) points out that this approach fails to capture an important element in alliances, namely the role of interfirm trust. In recent years, however, many scholars including transaction cost economists have emphasized the importance of trust in economic exchange (Poppo \& Zenger, 2002). Das and Teng (1998), for example, argue that firms enter a strategic alliance only if they have an adequate level of confidence in its partner's cooperative behavior. They argue that confidence in partner cooperation comes from two distinct sources: trust and control. Although the literature on trust is burgeoning, there is still a lot of confusion on the concept of trust and its different facets. In this paper we use the term relational capital as introduced by Kale, Singh, and Perlmutter (2000). They define relational capital as mutual trust, respect and friendship between alliance partners. 
Relational capital is akin to the knowledge-based trust referred to by Gulati (1995) or the behavioral trust referred to by Madhok (1995) (Kale et al., 2000).

The benefits of relational capital or trust in strategic alliances are numerous, including lowering transaction costs (Gulati, 1995), learning (Kale et al., 2000), strategic flexibility (Young-Ybarra \& Wiersema, 1999), and reducing relational risk (Nooteboom et al., 1997). Kale et al. (2000) show in their empirical study that the greater the relational capital between the alliance partners, the greater will be the degree of learning achieved as well as the greater will be the ability to protect core proprietary assets from each other. In addition, Young-Ybarra and Wiersema (1999) argue that trust between firms has a positive impact on the ability of the partners to adjust to changing environments, i.e., trust has a positive impact on strategic flexibility. Furthermore, Nooteboom, Berger, and Norderhaven (1997) point out that relational risk in alliances has two dimensions: size of loss, and probability of loss. In their empirical study they could confirm the hypothesis that trust has a negative effect on relational risk in the form of the perceived probability of loss. Finally, Ireland et al. (2002) suggest that trust is a component of a "cooperative competency" that might be a firm-specific resource that leads to competitive advantage.

It has been argued that firms in an alliance have two mechanisms for making behavior predictable: detailed contracts and trust (Gulati, 1995). Relational capital and formal contracts are generally viewed as substitutes (Poppo \& Zenger, 2002). Gulati (1995: 93) argues "trust counteracts fears of opportunistic behavior and as a result, is likely to limit the transaction costs associated with an exchange.... In other words, trust can substitute for hierarchical contracts in many exchanges." There are at kast two arguments why trust and formal contracts can be understood as substitutes. Firstly, trust economizes on costly contracts. People who trust each 
other have less need to impose control on others (Woolthuis, Hillebrand, \& Nooteboom, 2002; Zand, 1972). Trust involves the expectation of reduced opportunistic behavior (Ebers, 2002), mitigating the need for detailed contracting (Jarillo, 1988; Gulati, 1995). Secondly, some authors show that detailed contracting may actually even destroy trust, for example by promoting a stigmatization process (Sitkin, 1995) or by sowing the seed for mutual suspicion (Macauley, 1963). Based on these arguments, we propose the following hypothesis:

H2: $\quad$ The contractual complexity of an entrepreneurial alliance will be negatively related to relational capital.

\section{Search Costs}

A related problem that firms face in managing interfirm collaboration is the challenge of finding a suitable alliance partner in the first place. Searching for potential exchange partners can be costly given the various expenses associated with the scanning of parties and the employment of agents in the process (e.g., Arrow, 1974). Prior research has noted that small businesses in particular are often costly to locate as exchange partners (Deeds, DeCarolis, \& Coombs, 1999), and they also find it more difficult to signal their business prospects to investors in a credible fashion (e.g., McConnell \& Pettit, 1984; Becchetti \& Trovato, 2002). These ex ante transaction costs provide rationales for the benefits of localizing transactions (e.g., Stigler, 1961) as well as for the drop-off in trade that occurs as distance increases, above and beyond that which might be accounted for by transportation costs and other factors (McCallum, 1995).

These inefficiencies in the market for alliance partners suggest that alliance termination may adversely affect entrepreneurial firms, even if their commitments to a collaborative arrangement are not entirely partner-specific. Because search costs for an alliance partner are sunk and these costs would need to be incurred in locating a new partner, the firm has an incentive to design a more complex contract to allocate duties, design processes for 
unforeseeable outcomes, and specify exchanges and remedies in more precise terms. The greater the search costs involved in locating a partner for a particular transaction, the greater the firm's incentive to bear the costs in designing more complex contractual arrangements. By contrast, if the firm can find an alternative partner with relative ease, the contract can be comparatively simple since the costs of switching to another exchange partner are lower, and it is therefore more likely that the relationship will be self-enforcing. We therefore hypothesize:

\section{H3: $\quad$ The contractual complexity of an entrepreneurial alliance will be positively related to the costs of searching for a partner.}

\section{Strategic Importance of the Alliance}

The previous hypotheses suggest efficiency-based reasons why firms may design more complex alliance agreements. We suspect that firms will also set up more complex alliance contracts for strategically important alliances for similar reasons. Alliances formed decades ago tended to be equity joint ventures in developing countries, often in less advanced industries. Taking on a local partner was often the price of entering a new market, and the foreign investor typically desired to enter the country on a stand-alone basis. Frequently such collaborators represented diversification outside of the firm's core business (Stopford \& Wells, 1972). By contrast, alliances formed today are increasingly being entered into by actual or potential competitors, involve two-way flows of knowledge, and often rely on multiple partners or are embedded in industry networks (e.g., Larson, 1991, 1992; Hara \& Kanai, 1994; Gomes-Casseres, 1997). Such alliances will tend to involve greater downside risks for collaborators relative to alliances that are more peripheral to the firm's strategy. These risks are in part a function of the greater control and coordination challenges posed by strategically important alliances relative to alliances that are not central to the firm's strategy, resource base, and objectives. 
In light of these risks, firms may seek a more complex contract for strategically important alliances for several reasons. The firm has an incentive to specify clearly the scope of the alliance and to clarify rights and obligations concerning what is outside of the immediate scope of the alliance (e.g., confidential information) as well as what is produced during the time span of the collaboration (e.g., proprietary technology) (e.g., Borys and Jemison, 1989). Given the risk of creating or shoring up a competitor, parties also have an interest in specifying clearly how the alliance will end to guard against valuable resources falling into the hands of a competitor or third party. Process issues such as the mechanisms facilitating the control of the alliance (e.g., notification and auditing rights, reporting, etc.), the means by which disputes will be resolved (e.g., arbitration provisions, lawsuits, etc.), and ways in which the alliance's development will be managed (e.g., Ring and Van de Ven, 1994) will also tend to be more salient for such alliances. We therefore hypothesize:

\section{H4: $\quad$ The contractual complexity of an entrepreneurial alliance will be positively} related to the strategic importance of the alliance.

\section{METHODS}

\section{Sample}

The research sample focused on alliances in the German telecommunications industry. According to Section 4 of the German telecommunications law, every company that wants to offer telecommunication services is required to notify the regulatory authority. Therefore, the register of the German regulatory authority for telecommunication and postal services was used as the starting data source for this stud y. This register is updated twice a year and is publicly available. Targeted respondents in this study were all telecommunication companies that owned a class 3 license (i.e., a network license allowing the company to build network infrastructure), 
or a class 4 license (i.e., a service license allowing the company to offer voice telephony to the public) according to $\S 6$ of the German telecommunications law.

In total, 257 companies were identified that owned a class 3, a class 4, or both licenses. Of the 257 questionnaires mailed, 83 questionnaires were obtained, representing a 32 percent response rate. The high response rate may be attributed to the follow-up procedure of sending a reminder letter and of making supplemental phone calls (Dillman, 1978). In addition, the guarantee of confidentiality and a report on the main results of the study can be regarded as further incentives to answer the questionnaire. Furthermore, the study was supported by two letters of recommendation of the leading telecommunication industry federations. As an illustration of the competence and appropriateness of key informants, 65 percent were members of the board and were involved in the formation of the collaborative agreement. Given the objectives of our study, our analysis focused on the alliances of small firms (i.e., 70 of the 83 , or 84.3 percent) based on a cut-off value of 500 employees (e.g., Roy \& Simpson, 1981). These firms averaged four years in age. Four of the questionnaires were incomplete for our purposes, leaving a final sample size of 66 alliances.

Several steps were taken to ensure the validity of the data. Preliminary versions of the questionnaire were reviewed by four business scholars and nine practitioners from the telecommunications industry to ensure face validity. Variables that were previously used in US empirical studies were translated into German and reviewed by two German-speaking researchers. After the data were collected, in order to assess potential nonresponse bias, we tested for possible differences between early and late respondents, under the assumption that late respondents are more similar to non-respondents than early respondents are to non-respondents (Armstrong and Overton, 1977). We tested for differences in firm size based on number of 
employees and sales. A one-way analysis of variance (ANOVA) for firm size across early and late respondents yielded an insignificant F-value of 0.02 for number of employees and 0.12 for sales. Additional tests examining early and late respondents for differences in alliance experience based on the number of current alliances and experiences with alliances in the past were similarly insignificant. Thus, we found no evidence of response bias.

Although our primary dependent variable is an objective measure of contractual complexity, we also sought to address the possibility of consistency artifacts and common method bias. Specifically, we used Harman's (1967) single-factor test to examine whether a significant amount of common method variance exists in the data. If so, a factor analysis of all of the variables will generate a single factor or a general factor that accounts for most of the variance in the data (e.g., Podsakoff \& Organ, 1986). Unr otated factor analysis using the eigenvalue-greater-than-one criterion revealed four factors, and the first factor explained only 24.1 percent of the variance in the data. Thus, we concluded that the analysis was not subject to common methods bias.

\section{Measures and Model Specification}

Contractual complexity. In prior research in economics, contracts have tended to be modeled following one of two approaches. Some research has relied on very broad measures of contractual completeness, including proxies such as the mere length of the contract (Joskow, 1988) or a subjective rating of the degree to which parties instituted provisions to deal with future contingencies that might arise in an exchange relationship (e.g., Macneil, 1978). At the opposite extreme, other studies have examined very specific provisions appearing in contracts, in effect separating particular provisions from other aspects of a contractual arrangement in order to study them more closely. Examples of studies falling into this later category include work on 
territorial restrictions in licensing agreements (e.g., Mueller and Geithman, 1991), payment structures in franchising agreements (e.g., Lafontaine, 1992), and specific pricing provisions in supply contracts (e.g., Crocker and Reynolds, 1993), among others.

In this study, we rely upon a series of indicators of contractual provisions in alliances that have been used in prior work by Parkhe (1993) in the domain of strategic alliances. Specifically, he conducted a computer-assisted search of the legal literature and arrived at the following eight provisions, which appear in increasing order of stringency: (1) periodic written reports of all relevant transactions, (2) prompt written notice of any departures from the agreement, (3) the right to examine and audit all relevant records through a firm of CPAs, (4) designation of certain information as proprietary and subject to confidentiality provisions of the contract, (5) non-use of proprietary information even after termination of agreement, (6) termination of agreement, (7) arbitration clauses, and (8) lawsuit provisions. Based on these eight provisions, we adopted his stringency-weighted measure of contractual completeness, which is constructed as follows:

(1) Contractual complexity (weighted) $=\frac{1}{36} \sum_{i=1}^{8} D_{i}$, where $D_{i}$ equals $i$ if the ith provision was employed, and zero otherwise. In other words, $D_{i}$ equals one if the first provision was employed, zero otherwise; two if the second provision was employed, zero otherwise; and so on. The summation term therefore ranges from 0 to 36 , and the division by 36 yields a measure ranging from zero to one. When the variable takes on a value of zero, none of the eight provisions listed above is in place. When the variable assumes its maximum value of one, all of the eight provisions appear in the alliance agreement.

In order to test the sensitivity of the results to the weighting scheme employed, we also constructed multivariate models using an unweighted measure of contractual complexity as the dependent variable. This measure was defined as follows: 
(2) Contractual complexity (unweighted) $=\sum_{i=1}^{8} X_{i}$,

where $X_{i}$ equals 1 if the ith provision was employed, and zero otherwise. The summation therefore is an integer variable ranging from zero to eight, and specifications reliant on this dependent variable were estimated using ordered logit models.

Explanatory variables. The fist variable that we included in the multivariate models to test H1 is Asset specificity. This measure was constructed as an unweighted index based on three indicators, each of which were measured on a five-point scale ranging from 'negligible' to 'substantial:' "Our investment in dedicated personnel specific to this venture is ...," "Our investment in dedicated facilities specific to this venture is...," and "If we decided to stop this venture, the difficulty we would have in redeploying our people and facilities presently serving the venture to other uses would be..." (e.g., Anderson \& Weitz, 1992). The Cronbach alpha for this index is 0.75 , indicating that it demonstrates satisfactory reliability (Nunnally, 1978). When we performed an unrestricted factor analysis for these indicators, they all loaded on a single factor with an eigenvalue of 1.68 based on the eigenvalue greater than one criterion, and the factor loadings for the items were $0.78,0.78$, and 0.67 , respectively.

In order to test the second hypothesis (i.e., Relational capital), we constructed a scale that captures the mutual trust and respect between contracting parties. Specifically, we implemented the measure of Kale, Singh, and Perlmutter (2000). This index was constructed based on five indicators ranging from ' 1 - strongly disagree' to '5 - strongly agree': “There is close, personal interaction between the partners at multiple levels," "The alliance is characterized by mutual respect between the partners at multiple levels," "The alliance is characterized by mutual trust between the partners at multiple levels," "The alliance is characterized by personal friendship between the partners at multiple levels," and "The alliance is characterized by high reciprocity 
among the partners" (Kale, Singh, \& Perlmutter, 2000). The Cronbach alpha for this index is 0.83, providing evidence of satisfactory reliability (Nunnally, 1978). When we performed an unrotated factor analys is of these indicators, all five loaded on a single factor with an eigenvalue of 3.28 based on the eigenvalue greater than one criterion, and the factor loadings were 0.82 , $0.84,0.87,0.77$, and 0.72 , respectively.

The search costs variable used to test $\mathrm{H} 3$ captures the efforts expended by management to search for the alliance partner (i.e., Search costs). Respondents were asked to indicate on a fivepoint scale the effort it took for the firm to search for its alliance partner. The measure ranged from a value of one for 'very low' to five for 'very high.' Strategic importance, the variable used to test our final hypothesis, was measured in a similar fashion. Respondents were asked to indicate the strategic importance of the alliance to the firm. The measure relied on a five-point Likert scale ranging from 'strongly disagree' to 'strongly agree.'

Control variables. While our primary objective was to deve lop a parsimonious model that can explain entrepreneurial firms' decisions concerning the number and stringency of provisions they institute into their alliance contracts, we also sought to control for other factors that might be related to these decisions as well as the independent variables noted above. First, we incorporated a control for the scope of the alliance (i.e., Alliance scope). Broader alliances are more complicated to monitor and coordinate and such alliances may be of greater strategic importance to entrepreneurial firms. By contrast, alliances with a narrower scope are likely to be simpler to manage, may be less central to the firm's strategy, and may be more reversible (Borys \& Jemison, 1989). In order to measure this variable, we developed a list of seven functions that an alliance in the telecom sector might cover, ranging from procurement and the operation of 
basic infrastructure to billing and customer relations. The alliance scope measure indicated how many of these seven functions fell under the operational responsibility of the alliance.

Second, the complexity of an alliance can reflect not only the number of functional activities performed by the alliance, but also the number of partners seeking to coordinate their activities. We therefore used an indicator variable to control for whether the alliance was between multiple partners or was purely dyadic in nature (i.e., Multiple partners). Alliances bringing together multiple partners with different interests will be more difficult to manage, whereas dyadic alliances will tend to be more straightforward, holding everything else constant. Results similar to those presented below were obtained when this control was measured instead as a continuous variable defined to be the number of partners in the alliance.

For similar reasons, we included a control to indicate whether or not the collaboration was a cross-border alliance versus a domestic collaborative agreement. There also may be enforceability concerns or legal barriers to developing more complex alliance contracts for crossborder collaborative agreements. However, less information tends to be known about foreign firms than domestic firms, and character-based trust tends to emerge more readily between firms that are socially similar (Zucker, 1986). This also suggests that behavioral uncertainty and perceptions of opportunistic behavior may be more likely to arise in cross-border alliances. The indicator variable Foreign takes on a value of 1 for international alliances and 0 for alliances between German firms.

Finally, we controlled for the age of the firm in years (i.e., Firm age). This variable helps to account for other sources of heterogeneity at the parent firm level. For example, younger firms may lack the experience, slack resources, and staff to create more sophisticated alliance 
agreements, whereas these resources and administrative skills are more apt to be present in firms that are somewhat older (e.g., Niederkofler, 1991).

Model specification. The basic structure of the different models, which test the factors associated with the degree of contractual complexity in entrepreneurial alliances, is as follows:

(3) Contractual complexity $=\beta_{0}+\beta_{1}$ Asset specificity $+\beta_{2}$ Relational capital $+\beta_{3}$ Search costs $+\beta_{4}$ Strategic importance $+\beta_{5}$ Alliance scope $+\beta_{6}$ Multiple partners $+\beta_{7}$ Foreign $+\beta_{8}$ Firm age $+\varepsilon$.

In order to examine how these antecedents of contractual provisions in alliances compare with those shaping firms' governance decisions, the following logit model was also estimated to differentiate equity and non-equity alliances:

(4) Equity $=\beta_{0}+\beta_{1}$ Asset specificity $+\beta_{2}$ Relational capital $+\beta_{3}$ Search costs $+\beta_{4}$ Strategic importance $+\beta_{5}$ Alliance scope $+\beta_{6}$ Multiple partners $+\beta_{7}$ Foreign $+\beta_{8}$ Firm age + $\varepsilon$.

\section{RESULTS}

Figure 1 graphically depicts the distribution of contractual provisions for the final sample. The average number of provisions appearing in alliance contracts is 5.1, and the modal number is 6 . These indicators of central tendency, combined with the relatively peaked distribution of contractual provisions, indicate that the contracts are relatively complexin general. At the same time, just as very few alliances have only one or two provisions, very few contracts involve all eight provisions.

$==================$
Insert Figure 1 about here
$================$

Table 1 expands upon these overall patterns in two ways by reporting the incidence of particular contractual provisions in alliances as well as by separating non-equity and equity 
governance structures. This table reveals that nearly all alliance contracts involve termination provisions (i.e., 92 percent), confidentiality provisions (i.e., 91 percent), and restrictions on proprietary information (i.e., 88 percent). This finding is consistent with the selection of alliances in a high-tech domain such as telecommunications. At the opposite end of the spectrum, comparatively few alliances involve auditing rights (i.e., 15 percent), which can be attributed to the fact that auditing rights tend to be used more routinely in equity alliances involving a separate business entity requiring monitoring and control $(\mathrm{p}<0.01)$, and the lion's share of sampled alliances are non-equity alliances (i.e., 86 percent) rather than equity alliances (i.e., 14 percent). It is also plausible that equity alliances tend to rely more on provisions for notification rights for relevant transactions since such collaborative arrangements tend to involve a separate business entity. It is also striking, however, that no differences exist across non-equity and equity for the other individual provisions. This contractual heterogeneity contrasts prior treatments of alliances that assume that equity structures necessarily involve greater control over alliances than non-equity arrangements.

Insert Table 1 about here

Table 2 explores the extent to which the eight different provisions bundle together. Column values in the middle of the table indicate the likelihood that provision $\mathrm{i}$ will be in place, conditional upon the provision listed in the left-most portion of the row appearing in the alliance contract. In the vast majority of cases, these conditional relative frequencies are larger than the unconditional relative frequencies for individual provisions, which is suggestive of complementary usage of the different contractual clauses. The variance in the values within a column also indicates the provisions which are more or less likely to be used in concert with one 
another. For example, notification rights for departures to the agreement (i.e., provision 2) appear in only half of the alliance contracts that have auditing rights specified, whereas these notification rights are negotiated in as many as 96 percent of the contracts that rely on arbitration provisions. By contrast, the usage of termination clauses (i.e., provision 6) is relatively insensitive to the usage of other contractual provisions in alliances. In a similar fashion, while the usage of auditing rights does vary across equity and non-equity alliances and is relatively low overall, the incidence of provisions for auditing rights is fairly insensitive to the presence or absence of most of the other contractual provisions.

Insert Table 2 about here

Descriptive statistics and a correlation matrix appear in Table 3. Roughly 42 percent of the sampled alliances involved more than two partners. Sixteen percent involved three partners, 12.9 four partners, and 14.5 five or more partners. Only fifteen percent of the collaborative agreements were cross-border alliances, however. Thirty-two percent of respondents strongly agreed that the alliance was strategically important to the firm. For such alliances, firms tended to engage in more extensive search processes for partners $(\mathrm{p}<0.05)$ and make greater transactionspecific investments in the collaboration $(\mathrm{p}<0.001)$. Firms tended to make transaction-specific investments and engage in strategically important alliances with trusted partners $(\mathrm{p}<0.05$ and $\mathrm{p}<0.01$, respectively. Alliances with greater asset specificity also tended to involve a broader range of functional activities falling under the operational responsibility of the alliance $(\mathrm{p}<0.05)$. Finally, the average age of the firms comprising the sample was four years, and there is modest evidence that the youngest firms in the sample had to devote greater effort to the search for an 
alliance partner and had to make less redeployable commitments to their collaborative agreements (both $\mathrm{p}<0.10$ ).

Insert Table 3 about here

Table 4 presents the results of the multivariate analyses. Models 1 and 2 rely on the unweighted, or count-based, measure of contractual complexity. Because this dependent variable is discrete rather than continuous, these two models are estimated using ordered logit. Models 3 and 4 use the stringency-weighted measure of contractual completeness (i.e., see equation 3) and therefore are estimated using standard OLS. For comparison purposes, Models 5 and 6 represent governance structure models that differentiate non-equity and equity alliances rather than examine the number or stringency of provisions that firms put into their alliance contracts. These two equations were estimated using logit models. Models 1, 3, and 5 serve as baseline specifications in which the controls alone appear. Models 2, 4, and 6 are the full models that add the effects of the theoretical covariates, and all three of these models are significant on an overall basis $(\mathrm{p}<0.01, \mathrm{p}<0.01$, and $\mathrm{p}<0.001$, respectively $)$. A likelihood ratio test for the models using the unweighted measure of contractual complexity suggests that the theoretical variables are jointly significant $(\mathrm{p}<0.001)$. In a similar fashion, a hierarchical F-test indicates that these variables are jointly significant when the stringency-weighted contractual complexity variable is used instead $(\mathrm{p}<0.01)$. Finally, a likelihood ratio test reveals that the theoretical variables are significant as a group in explaining firms' governance decisions in the form of their choices to adopt non-equity versus equity structures for their alliances $(\mathrm{p}<0.001)$.

Insert Table 4 about here 
Our first hypothesis suggested that firms will tend to negotiate more complex contracts when making transaction-specific investments in an alliance. In Models 2 and 4, there is no support for this prediction, however. The results from the governance choice models do suggest that asset specificity relates instead to the decision to adopt an equity alliance over a non-equity alliance. In the presence of exchange hazards such as hold-up surrounding transaction-specific investments, equity alliances are preferable to non-equity structures since the former provide incentive alignment through joint ownership and greater coordination through a joint board (Hennart, 1988). This result is consistent with prior research on the antecedents of governance choices in alliances (Pisano, 1989; Oxley, 1997). However, the finding that firms tend to rely on this discrete structural alternative and not on building in greater contractual complexity differs from prior evidence on contract design and the role of transaction-specific investments (e.g., Joskow, 1988; Poppo \& Zenger, 2002). In order to examine whether asset specificity leads to greater contractual complexity in alliances without additional governance mechanisms in place, the contractual provisions models were re-estimated for non-equity alliances alone, and similar insignificant results were obtained for both the weighted and unweighted measures of contractual completeness.

Our second hypothesis was concerned with the relationship between contractual complexity and alliance partners' relational capital. The results for this variable closely parallel those for asset specificity noted above. Specifically, firms tend to use nonequity rather than equity alliances when they have mutual respect and trust (Gulati, 1995), yet they do not appear to institute or avoid more precise contractual safeguards when such respect and trust is lacking or present. Parameter estimates for the relational capital variable for models using the weighted and unweighted measures of contractual complexity in the non-equity alliance subsample were 
directionally consistent with the hypothesis, but again did not reach statistical significance. In order to examine the possibility that relational capital might have an indirect influence by moderating the effects of asset specificity or strategic importance, we developed interaction terms for these variables, but no evidence was found for such relationships.

Our third hypothesis suggested that firms will negotiate more, and more stringent, provisions into their alliance contracts when it was costly to search for an alliance partner. The results in Models 2 and 4 support this prediction. The greater the search costs for an alliance partner, the greater the complexity of the alliance contract (both $\mathrm{p}<0.05$ ). However, firms that have undertaken a significant search process for a partner do not necessarily choose an equitybased alliance for the exchange relationship rather than a non-equity arrangement.

Finally, our fourth prediction suggested that firms will negotiate more complex alliance contracts for alliances viewed as strategically important. The results provide support for this hypothesis. In Models 2 and 4, it is evident that more strategically important alliances tend to involve more complex contracts, while alliances that are less strategically central to the firm are apt to be governed by comparatively simple contractual arrangements (both $\mathrm{p}<0.01$ ). The results from the governance choice models, however, provide no evidence that strategically important alliances are any more likely to be structured as equity rather than non-equity alliances. Interestingly, the results for the control variables indicate that neither the contractual complexity of alliance agreements nor their governance structures are shaped by considerations such as how broad or narrow the alliance's scope is and whether or not the alliance involves a foreign parent or multiple partners. The multivariate results provide modest evid ence in line with the bivariate finding that young firms tend to negotiate more complex contracts $(\mathrm{p}<0.10)$. 


\section{DISCUSSION}

The results from this study show that contractual complexity is driven by the costs of searching for a new partner, and by the strategic importance attached to the alliance. However, contrary to what we had expected, we did not find evidence that asset specificity or relational capital influence contractual complexity. Interestingly, we found that firms' decisions concerning contractualcomplexity and governance structure have distinct antecedents. In particular, the latter is driven by asset specificity and relational capital, but not by the alliance's strategic importance or search costs.

The results for asset specificity and relational capital pose an intriguing puzzle, as one would expect partners would try to protect themselves from hold-up risk by including more stringent clauses in the contract, and the same applies for alliance partners that do not share mutual respect and trust. Given that asset specificity has been linked to contractual complexity in contracts in other domains (e.g., Joskow, 1988), this result may reflect our sampling of telecommunications companies. Given the high technological uncertainty present in this environment, the likelihood of contractual renegotiation is very likely, so complex contracts are also likely to require costly renegotiations. Faced with the risk of hold-up under these circumstances, managers may prefer to protect themselves by turning to a governance solution instead of a contractual solution(e.g., Poppo \& Zenger, 2002).

As for relational capital, firms have an opportunity to cultivate it when they have other common relationships, either concurrent to the focal agreement or in the past When partners have worked together in other alliances, they have discussed certain conditions and agreed on them already. To the extent that some of these conditions are "boilerplate" or common terms, including them in a new alliance contract entails no incremental cost (Ring, 2002). This may 
explain why contracts for alliances between partners with a high relational capital may be as complex as those of alliances between companies with a lower level of relational capital. In fact, this interpretation is consistent with findings showing that contracts of alliances between partners with prior ties are at least as complex in terms of specificity as those in which partners have had no previous relationships, in part because boilerplate terms are used repeatedly (Luo, 2002; Ryall and Sampson, 2003). Our interpretation is also consistent with evidence that in the presence of prior ties contracts contain more provisions on how to respond to future problems, conflicts and contingencies (Luo, 2002). In sum, this suggests that the trust developed through past relationships can complement contractual partner control. This argument is in consonance with findings by Poppo and Zenger (2002) in the context of information service exchanges.

On the other hand, our findings suggest that when the parties enjoy a certain level of relational capital they are more likely to choose non-equity forms of governance. The opportunity to interact in other common alliances provides partners an occasion to develop interorganizational routines that make their behavior more predictable (Zollo, Reuer, \& Singh, 2002). This argument complements that of Gulati and Singh (1998), who show that trust not only mitigates appropriation concerns but also alleviates concerns about coordination costs. They argue that trusting firms have a greater awareness of the rules, routines and procedures that each company follows which makes it easier to manage the interface in the alliance and to process necessary information. As a result, trust between alliance partners is likely to necessitate fewer hierarchical controls, because coordination costs are more easily managed.

Our results also show that alliance contracts are fairly heterogeneous. While roughly half of the alliances in our sample have 5 or 6 contractual clauses, the other half is broadly distributed. In addition, there are few significant differences in the use of particular contractual 
clauses in equity and non-equity alliances. These differences appear in the use of two of the least stringent clauses (rights to reports of relevant transactions and auditing rights). These findings are consistent with the fact that contractual complexity has different antecedents than governance form, and there appears not to be a simple mapping between contractual complexity and governance form. Based on this evidence, the assumption that control tends to increase in a simple fashion when moving from non-equity to equity alliances may be questioned.

One implication of our study for researchers investigating alliance contracts is that it does not matter whether measures of contractual complexity use stringency weights or not. In fact, both measures are highly correlated $(r=0.94, p<.001)$, and the results hold the same in the models using weighted or unweighted measures of contractual complexity. Future studies might consider whether or not weighting schemes are required for different types of contractual provisions or for alliances in different sectors. Because we have focused on classes of contractual provisions, extensions that probe further the specific clauses firms use and the alternative ways of negotiating these elements would also be valuable and provide guidance to entrepreneurs seeking to design their collaborative agreements.

Entrepreneurs will also need to consider the tradeoffs between contractual complexity and flexibility when designing their alliances. On the one hand, entrepreneurial firms tend to have less resources to design more complex contracts than established firms, and prolonged efforts to craft alliance agreements may detract attention from other important activities (Inkpen and Ross, 2001). In fact, flexibility is often a key objective for entering into alliances in the first place. On the other hand, established firms may be in a better position to manage subsequent stages of an alliance's evolution to their advantage (Reuer and Ariño, 2002). 
Several of the limitations of this study open up additional opportunities for further research on the contractual design of collaborative agreements. First, the study is based on a sample of firms operating in one country and one industry. Extensions could therefore take up the issue of whether our results generalize broadly to other alliances or whether there are bounds on such generalizability. Given that many national cultures tolerate higher levels of uncertainty than Germany (Hofstede, 1980) and that the telecommunications industry involves particular business and technological risks, we suspect that alliance contracts in other industries or countries may be more open and may even be shaped in different ways by various exchange hazards. Second, although our study has focused on entrepreneurial firms, and this is one of its strengths, extensions that explicitly compare entrepreneurial firms and established firms engaged in alliances would be valuable. Finally, we have examined here but one particular aspect of alliance design. Investigating other alliance formation issues such as partner selection, negotiation processes, the intervention of outside professionals such as lawyers, etc. may add to our understanding of how entrepreneurial firms might use and manage alliances to advance their objectives and overcome some of the fundamental challenges of interfirm cooperation. 


\section{REFERENCES}

Acs, Z. J. and Audretsch, D. B. 1987. Innovation, market structure, and firm size. Review of Economics and Statistics 69: 567-574.

Anderson, E., and Weitz, B. 1992. The use of pledges to build and sustain commitments in distribution channels. Journal of Marketing Research 29: 18-34.

Armstrong, J.S., and Overton, T.S. 1977. Estimating nonresponse bias in mail surveys. Journal of Marketing Research 14: 396-403.

Arrow, K. J. 1974. The limits of organization. New York: W. W. Norton.

Becchetti, L., and Trovato, G. 2002. The determinants of growth for small and medium sized firms: The role of the availability of external finance. Small Business Economics 19: 291306.

Borys, B., and Jemison, D.B. 1989. Hybrid arrangements as strategic alliances: Theoretical issues in organizational combinations. Academy of Management Review 14: 234-249.

Coombs, J.E., and Deeds, D.L. 2000. International alliances as sources of capital: Evidence from the biotechnology industry. Journal of High Technology Management Research 11: 235253.

Covin, J.G. and Slevin, D.P. 1991. A conceptual model of entrepreneurship as firm behavior. Entrepreneurship Theory and Practice 16(1): 7-25.

Crocker, KJ., and Reynolds, KJ. 1993. The efficiency of incomplete contracts: An empirical analysis of Air Force engine procurement. RAND Journal of Economics 24: 126-146.

Das, T.K., and Teng, B.-S. 1998. Between trust and control: Developing confidence in partner cooperation in alliances. Academy of Management Review 23: 491-512.

Deeds, D., DeCarolis, D. and Coombs, J.E. 1999. Dynamic capabilities and new product development in high technology ventures: An empirical analysis of new biotechnology firms. Journal of Business Venturing 15: 211-229.

Deeds, D.L., and Hill, C.W. 1999. An examination of opportunistic action within research alliances: Evidence from the biotechnology industry. Journal of Business Venturing 14: 141-163.

Dickson, P.H., and Weaver, K.M. 1997. Environmental determinants and individual-level moderators of alliance use. Academy of Management Journal 40: 404-425.

Dillman, D. 1978. Mail and telephone surveys: The total design method. New York: Wiley. 
Doz, Y.L. 1988. Technology partnerships between larger and smaller firms: Some critical issues. In Contractor, F.J., Lorange, P. (Eds.), Cooperative strategies in international business. Lexington, MA: D. C. Heath.

Egelhoff, W.G., and Haklisch, C.S. 1994. Strategy, size of firm, and the use of technical alliances: An exploratory study. Journal of Engineering and Technology Management 11: $117-148$.

George, G., Zahra, S.A., and Wood, D. R. 2002. The effects of business-university alliances on innovative output and financial performance: A study of publicly traded biotechnology companies. Journal of Business Venturing 17: 577-609.

Gomes-Casseres, B. 1997. Alliance strategies of small firms. Small Business Economics 9: 3344.

Gulati, R. 1995. Does familiarity breed trust? The implications of repeated ties for contractual choice in alliances. Academy of Management Journal 38: 85-112.

Gulati, R., and Singh, H. 1998. The architecture of cooperation: Managing coordination costs and appropriation concerns in strategic alliances. Administrative Science Quarterly 1998: 781-814.

Hara, G., and Kanai, T. 1994. Entrepreneurial networks across oceans to promote international strategic alliances for small businesses. Journal of Business Venturing 9: 489-507.

Heide, J. 1994. Interorganizational governance in marketing channels. Journal of Marketing 58: 71-85.

Hennart, J.-F. 1988. A transaction cost theory of equity joint ventures. Strategic Management Journal 9: 361-374.

Hofstede, G. 1980. Culture's consequences: International differences in work-related values. Beverly Hills, CA: Sage.

Inkpen, A.C., and Ross, J. 2001. Why do some strategic alliances persist beyond their useful life? California Management Review, 44(1): 132-148.

Ireland, R.D., Hitt, M.A., and Vaidyanath, D. 2002. Alliance management as a source of competitive advantage. Journal of Management 28: 413-446.

James, H.S., Jr. 2000. Separating contract from governance. Managerial and Decision Economics 21: 47-61.

Jarillo, C. 1988. On strategic networks. Strategic Management Journal 9: 31-41. 
Joskow, P. 1988. Asset specificity and the structure of vertical relationships: Empirical evidence. Journal of Law, Economics, and Organization 4: 95-118.

Kale, P., Singh, H., and Perlmutter, H. 2000. Learning and protection of proprietary assets in strategic alliances: Building relational capital. Strategic Management Journal 21: 217237.

Lafontaine, F. 1992. Agency theory and franchising: Some empirical results. RAND Journal of Economics 23: 263-283.

Larson, A. 1991. Partner networks: Leveraging external ties to improve entrepreneurial performance. Journal of Business Venturing 6: 173-188.

Larson, A. 1992. Network dyads in entrepreneurial settings: A study of the governance of exchange relationships. Administrative Science Quarterly 37: 76-104.

Lerner, J., and Merges, R.P. 1998. The control of technology alliances: An empirical analysis of the biotechnology industry. Journal of Industrial Economics 46: 125-156.

Luo, Y. 2002. Contract, cooperation and performance in international joint ventures. Strategic Management Journal 23: 903-920.

Macauley, S. 1963. Non-contractual relations in business: A preliminary study. American Sociological Review 28: 55-67.

Macneil, I.R. 1978. Contracts: Adjustments of long-term economic relations under classical, neoclassical, and relational contract law. Northwestern University Law Review 72: 854902.

Madhok, A. 1995. Opportunism and trust in joint venture relationships: An exploratory study and a model. Scandinavian Journal of Management 11(1): 57-74.

Marino, L., Strandholm, K., Steensma, H.K., and Weaver, K.M. 2002. The moderating effect of national culture on the relationship between entrepreneurial orientation and strategic alliance portfolio extensiveness. Entrepreneurship Theory and Practice 46: 145-160.

McCallum, J. 1995. National borders matter: Canada-U.S. regional trade patterns. American Economic Review 85: 615-623.

McConnell, J.J., and Pettit, R.R. 1984. Application of the modern theory of finance to small business firms. In Horvitz, Pettit. (Eds.) Problems in financing of small business. Vol.42. Part A. Greenwich Conn.: JAI Press.

Mueller, W.F., and Geithman, F.E. 1991. An empirical test of the free rider and market power hypotheses. Review of Economics and Statistics 73: 301-308. 
Niederkofler, M. 1991. The evolution of alliances: Opportunities for managerial influence. Journal of Business Venturing 6: 237-25

Nooteboom, B., Berger, H., and Noorderhaven, N. 1997. Effects of trust and governance on relational risk. Academy of Management Journal 40: 308-338.

Nunnally, J.C. 1978. Psychometric theory. (Second Edition). New York, NY: MacGraw-Hill.

Oxley, J.E. 1997. Appropriability hazards and governance in strategic alliances: A transaction cost approach. Journal of Law, Economics, and Organization 13: 387-409.

Park, S.H, and Kim, D. 1997. Market valuation of joint ventures: Joint venture characteristics. Journal of Business Venturing 12: 83-108.

Parkhe, A. 1993. Strategic alliance structuring: A game theoretic and transaction costs examination of interfirm cooperation. Academy of Management Journal 36: 794-829.

Pisano, G.P. 1989. Using equity participation to support exchange: Evidence from the biotechnology industry. Journal of Law, Economics, and Organization, 5: 109-126.

Podsakoff, P.M., and Organ, D.W. 1986. Self-reports in organizational research: Problems and prospects. Journal of Management 12: 531-544.

Poppo, L., and Zenger, T. 2002. Do formal contracts and relational governance function as substitutes or complements? Strategic Management Journal 23: 707-725.

Reuer, J.J., and Ariño, A. 2002. Contractual renegotiations in strategic alliances. Journal of Management 28(1): 47-68.

Ring, P.S. 2002. The role of contracts in strategic alliances. In Contractor, F., Lorange, P. (Eds.) Cooperative Strategies and Strategic Alliances. London, UK: Elsevier Science: 145-162.

Ring, P.S., and Van de Ven, A.H. 1994. Developmental processes of cooperative interorganizational relationships. Academy of Management Review 19: 90-118.

Roy, D.A., and Simpson, C.L. 1981. Export attitudes of business executives in the smaller manufacturing firm. Journal of Small Business Management 19: 16-22.

Ryall, M.D., and Sampson, R.C. 2003. Do prior alliances influence contract structure? Evidence from technology alliance contracts. Working paper, http://ssrn.com/abstract=396601

Sarkar, M.B., Echambadi, R.A.J., and Harrison, J.S. 2001. Alliance entrepreneurship and firm market performance. Strategic Management Journal 22: 701-712.

Shane, S.A. 1994. Are champions different from non-champions? Journal of Business Venturing 9(5): 397-421. 
Shane, S., and Venkataraman, S. 2000. The promise of entrepreneurship as a field of research. Academy of Management Review 25(1): 217-226.

Steensma, H.K., Marino, L., Weaver, K.M., and Dickson, P.H. 2000. The influence of national culture on the formation of technology alliances by entrepreneurial firms. Academy of Management Journal 43: 951-973.

Stigler, G.J. 1961. The economics of information. Journal of Political Economy 69: 213-225.

Stopford, J.M., \& Wells, L.T. 1972. Managing the multinational enterprise. New York, NY: Basic Books.

Weaver, K.M., and Dickson, P.H. 1998. Outcome quality of small- to medium-sized enterprisebased alliances: The role of perceived partner behaviors. Journal of Business Venturing 13: 505-522.

Williamson, O.E. 1985. The economic institutions of capitalism. New York, NY: Free Press.

Williamson, O.E. 1991. Comparative economic organization: The analysis of discrete structural alternatives. Administrative Science Quarterly 36: 269-296.

Woolthuis, R.K., Hillebrand, B, and Nooteboom, B. 2002. Trust and formal control in interorganizational relationships. Rotterdam: ERIM Report Series Research in Management: $1-18$.

Young-Ybarra, C., and Wiersema, M. 1999. Strategic flexibility in information technology alliances: The influence of transaction cost economics and social exchange theory. Organization Science 10: 439-459.

Zacharakis, A.L. 1997. Entrepreneurial entry into foreign markets: A transaction cost perspective. Entrepreneurship Theory and Practice 21: 23-39.

Zahra, S.A., Ireland, R.D., \& Hitt, M. A. 2000. International expansion by new venture firms: International diversity, mode of market entry, technological learning, and performance. Academy of Management Journal 43: 925-950.

Zand, D.E. 1972. Trust and managerial problem solving. Administrative Science Quarterly 17: 229-239.

Zollo, M., Reuer, J. J., \& Singh, H. 2002. Interorganizational routines and performance in strategic alliances. Organization Science 13: 701-713.

Zucker, L. G. 1986. Production of trust: Institutional sources of economic structure 1840-1920. In Staw, B.W., Cummings, L. L. (Eds.), Research in Organizational Behavior 8. Greenwich, CT: JAI Press. 
FIGURE 1

Distribution of Contractual Provisions ${ }^{\text {a }}$

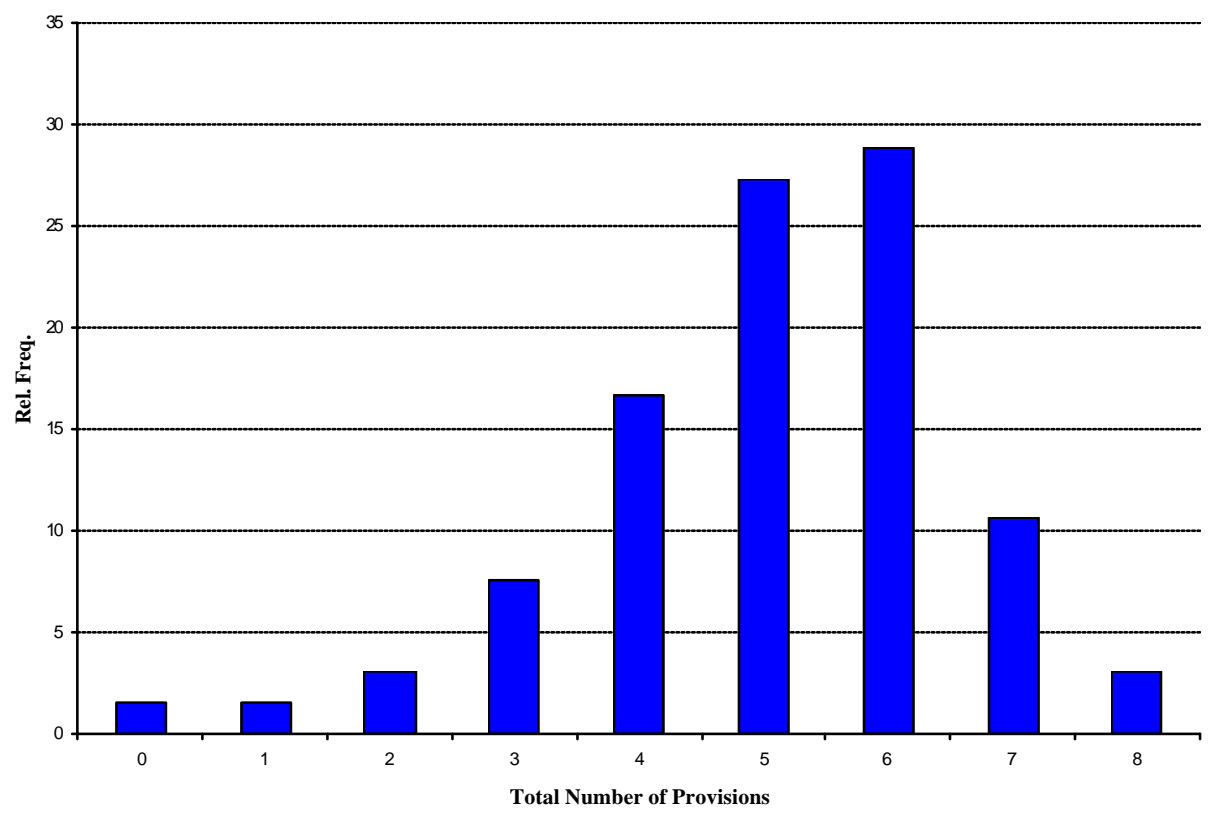

${ }^{\mathrm{a}} \mathrm{N}=66$. 
TABLE 1

Incidence of Specific Contractual Provisions across Non-equity and Equity Alliances

\begin{tabular}{|c|c|c|c|c|c|}
\hline Provision & $\overline{T o t a l}$ & $\begin{array}{l}\text { Non- } \\
\text { equity }\end{array}$ & Equity & $\overline{\chi^{2}}$ & t value \\
\hline 1. Rights to reports of relevant transactions & 0.41 & 0.35 & 0.78 & $5.86^{*}$ & \\
\hline 2. Notification rights for departures from the agreement & 0.82 & 0.82 & 0.78 & 0.11 & \\
\hline 3. Auditing rights & 0.15 & 0.11 & 0.44 & $6.96^{* *}$ & \\
\hline 4. Confidentiality provisions & 0.91 & 0.89 & 1.00 & 1.04 & \\
\hline 5. Restrictions on proprietary information & 0.88 & 0.88 & 0.89 & 0.01 & \\
\hline 6. Termination provisions & 0.92 & 0.93 & 0.89 & 0.19 & \\
\hline 7. Arbitration clauses & 0.41 & 0.42 & 0.33 & 0.25 & \\
\hline 8. Lawsuit provisions & 0.55 & 0.51 & 0.78 & 2.27 & \\
\hline Contractual completeness (weighted) & 0.65 & 0.64 & 0.72 & & -1.14 \\
\hline Contractual completeness (unweighted) & 5.05 & 4.91 & 5.89 & & $-1.79^{\dagger}$ \\
\hline $\mathrm{N}$ & 66 & 57 & 9 & & \\
\hline
\end{tabular}

${ }^{\mathbf{b} \dagger} \mathrm{p}<0.10,{ }^{*} \mathrm{p}<0.05,{ }^{* *} \mathrm{p}<0.01,{ }^{* * *} \mathrm{p}<0.001$. 
TABLE 2

Bundling of Contractual Provisions in Entrepreneurial Alliances

\begin{tabular}{|c|c|c|c|c|c|c|c|c|c|}
\hline \multirow[b]{2}{*}{ Provision } & \multirow[b]{2}{*}{$\begin{array}{c}\# \text { in Effect } \\
(\%)\end{array}$} & \multicolumn{8}{|c|}{ Conditional Relative Frequencies of Other Provisions } \\
\hline & & $(1)$ & $(2)$ & (3) & (4) & $(5)$ & $(6)$ & (7) & (8) \\
\hline 1. Rights to reports of relevant transactions & $27(40.9)$ & --- & 0.85 & 0.22 & 1.00 & 0.93 & 0.93 & 0.44 & 0.70 \\
\hline 2. Notification rights for departures from the agreement & $54(81.8)$ & 0.43 & - & 0.09 & 0.91 & 0.91 & 0.98 & 0.48 & 0.57 \\
\hline 3. Auditing rights & $10(15.2)$ & 0.60 & 0.50 & --- & 1.00 & 0.90 & 0.90 & 0.40 & 0.70 \\
\hline 4. Confidentiality provisions & $60(90.9)$ & 0.45 & 0.82 & 0.17 & --- & 0.95 & 0.93 & 0.42 & 0.57 \\
\hline 5. Restrictions on proprietary information & $58(87.9)$ & 0.43 & 0.84 & 0.16 & 0.98 & --- & 0.97 & 0.43 & 0.55 \\
\hline 6. Termination provisions & $61(92.4)$ & 0.41 & 0.87 & 0.15 & 0.92 & 0.92 & --- & 0.43 & 0.56 \\
\hline 7. Arbitration clauses & $27(40.9)$ & 0.44 & 0.96 & 0.15 & 0.93 & 0.93 & 0.96 & --- & 0.63 \\
\hline 8. Lawsuit provisions & $36(54.5)$ & 0.53 & 0.86 & 0.19 & 0.94 & 0.89 & 0.94 & 0.47 & --- \\
\hline Average & $41.6(0.63)$ & & & & & & & & \\
\hline
\end{tabular}


TABLE 3

Descriptive Statistics and Correlation Matrix ${ }^{c}$

\begin{tabular}{|c|c|c|c|c|c|c|c|c|c|c|c|c|}
\hline Variable & Mean & S.D. & (1) & (2) & (3) & (4) & (5) & (6) & (7) & (8) & (9) & (10) \\
\hline $\begin{array}{l}\text { 1. Contractual complexity } \\
\text { (unweighted) }\end{array}$ & 5.05 & 1.54 & -- & & & & & & & & & \\
\hline $\begin{array}{l}\text { 2. Contractual complexity } \\
\text { (weighted) }\end{array}$ & 0.65 & 0.21 & $0.94^{* * *}$ & --- & & & & & & & & \\
\hline 3. Equity & 0.14 & 0.35 & $0.22^{\dagger}$ & 0.14 & --- & & & & & & & \\
\hline 4. Asset specificity & 7.62 & 2.67 & 0.15 & 0.07 & $0.37^{* *}$ & --- & & & & & & \\
\hline 5. Relational capital & 18.49 & 4.14 & -0.01 & -0.002 & -0.03 & $0.28^{*}$ & - & & & & & \\
\hline 6. Search costs & 3.20 & 1.13 & $0.38^{* *}$ & $0.35^{* *}$ & $0.25^{*}$ & $0.22^{\dagger}$ & 0.20 & --- & & & & \\
\hline 7. Strategic importance & 3.79 & 1.13 & $0.40^{* * *}$ & $0.37^{* *}$ & 0.11 & $0.44^{* * *}$ & $0.34^{* *}$ & $0.25^{*}$ & - & & & \\
\hline 8. Alliance scope & 2.58 & 1.48 & 0.06 & 0.08 & $0.21^{\dagger}$ & $0.29^{*}$ & 0.04 & -0.04 & 0.20 & --- & & \\
\hline 9. Multiple partners & 0.42 & 0.50 & -0.13 & -0.09 & 0.02 & -0.12 & 0.08 & $-0.23^{\dagger}$ & -0.14 & $0.23^{\dagger}$ & - & \\
\hline 10. Foreign & 0.15 & 0.36 & -0.07 & -0.08 & 0.08 & 0.08 & 0.07 & 0.08 & 0.04 & -0.11 & -0.11 & --- \\
\hline 11. Firm age & 4.03 & 1.81 & $-0.26^{*}$ & $-0.23^{\dagger}$ & 0.02 & $-0.22^{\dagger}$ & 0.04 & $-0.23^{\dagger}$ & -0.03 & 0.11 & 0.17 & 0.09 \\
\hline
\end{tabular}

${ }^{\mathrm{c}} \mathrm{N}=66 .{ }^{\dagger} \mathrm{p}<0.10,{ }^{*} \mathrm{p}<0.05,{ }^{* *} \mathrm{p}<0.01,{ }^{* * *} \mathrm{p}<0.001$. 
TABLE 4

Estimation Results for Contractual Form and Governance Structure Models ${ }^{\mathrm{d}}$

\begin{tabular}{|c|c|c|c|c|c|c|}
\hline \multirow{3}{*}{ Independent Variable } & \multicolumn{4}{|c|}{ Contractual Form Models } & \multirow{2}{*}{\multicolumn{2}{|c|}{$\begin{array}{c}\text { Governance } \\
\text { Structure Models } \\
\begin{array}{c}\text { Equity vs. Non- } \\
\text { equity }\end{array}\end{array}$}} \\
\hline & \multicolumn{2}{|c|}{$\begin{array}{l}\text { Contractual } \\
\text { complexity } \\
\text { (unweighted) }\end{array}$} & \multicolumn{2}{|c|}{$\begin{array}{l}\text { Contractual } \\
\text { complexity } \\
\text { (weighted) }\end{array}$} & & \\
\hline & (1) & $(2)$ & (3) & (4) & (5) & (6) \\
\hline Intercept(s) & Incl. & Incl. & $\begin{array}{l}0.73^{* * *} \\
(0.08)\end{array}$ & $\begin{array}{l}0.49^{* *} \\
(0.15)\end{array}$ & $\begin{array}{l}-4.32^{* *} \\
(1.53)\end{array}$ & $\begin{array}{l}-47.82^{\dagger} \\
(28.80)\end{array}$ \\
\hline Alliance scope & $\begin{array}{l}0.16 \\
(0.16)\end{array}$ & $\begin{array}{l}0.05 \\
(0.17)\end{array}$ & $\begin{array}{l}0.02 \\
(0.02)\end{array}$ & $\begin{array}{l}0.01 \\
(0.02)\end{array}$ & $\begin{array}{l}0.53^{\dagger} \\
(0.31)\end{array}$ & $\begin{array}{l}0.88 \\
(1.09)\end{array}$ \\
\hline Multiple partners & $\begin{array}{l}-0.55 \\
(0.47)\end{array}$ & $\begin{array}{l}0.09 \\
(0.49)\end{array}$ & $\begin{array}{l}-0.04 \\
(0.06)\end{array}$ & $\begin{array}{l}0.02 \\
(0.05)\end{array}$ & $\begin{array}{l}-0.06 \\
(0.92)\end{array}$ & $\begin{array}{l}4.04 \\
(3.74)\end{array}$ \\
\hline Foreign & $\begin{array}{l}-0.29 \\
(0.62)\end{array}$ & $\begin{array}{l}-0.38 \\
(0.64)\end{array}$ & $\begin{array}{l}-0.03 \\
(0.07)\end{array}$ & $\begin{array}{l}-0.03 \\
(0.07)\end{array}$ & $\begin{array}{l}0.46 \\
(1.24)\end{array}$ & $\begin{array}{l}-6.05 \\
(5.01)\end{array}$ \\
\hline Firm age & $\begin{array}{l}-0.23^{\dagger} \\
(0.13)\end{array}$ & $\begin{array}{l}-0.24^{\dagger} \\
(0.14)\end{array}$ & $\begin{array}{l}-0.03^{\dagger} \\
(0.01)\end{array}$ & $\begin{array}{l}-0.02 \\
(0.01)\end{array}$ & $\begin{array}{l}0.09 \\
(0.25)\end{array}$ & $\begin{array}{l}2.03^{\dagger} \\
(1.21)\end{array}$ \\
\hline Asset specificity & & $\begin{array}{l}-0.11 \\
(0.10)\end{array}$ & & $\begin{array}{l}-0.02 \\
(0.01)\end{array}$ & & $\begin{array}{l}3.82^{\dagger} \\
(2.09)\end{array}$ \\
\hline Relational capital & & $\begin{array}{l}-0.05 \\
(0.06)\end{array}$ & & $\begin{array}{l}-0.01 \\
(0.01)\end{array}$ & & $\begin{array}{l}-0.95^{*} \\
(0.46)\end{array}$ \\
\hline Search costs & & $\begin{array}{l}0.55^{*} \\
(0.23)\end{array}$ & & $\begin{array}{l}0.05^{*} \\
(0.02)\end{array}$ & & $\begin{array}{l}3.88 \\
(2.73)\end{array}$ \\
\hline Strategic importance & & $\begin{array}{l}0.82^{* *} \\
(0.26) \\
\end{array}$ & & $\begin{array}{l}0.09^{* *} \\
(0.03) \\
\end{array}$ & & $\begin{array}{l}-0.66 \\
(1.87) \\
\end{array}$ \\
\hline $\begin{array}{c}\chi^{2} \\
-2\left[L\left(\beta_{\text {red. }}\right)-L\left(\beta_{\text {full }}\right)\right] \sim \chi^{2} \\
\text { F value } \\
\Delta \mathrm{F}\end{array}$ & 5.08 & $\begin{array}{l}22.28^{* *} \\
19.73^{* * *}\end{array}$ & 1.17 & $\begin{array}{l}2.99^{* *} \\
3.68^{* *} \\
\end{array}$ & 3.73 & $\begin{array}{l}31.50^{* * *} \\
27.78^{* * *}\end{array}$ \\
\hline
\end{tabular}

${ }^{\mathbf{d}} \mathrm{N}=66$. Standard errors appear in parentheses. Models 1 and 2 are estimated with ordered logit models, models 3 and 4 are estimated with ordinary least squares regression, and models 5 and 6 are estimated with logit models. ${ }^{\dagger} \mathrm{p}<0.10,{ }^{*} \mathrm{p}<0.05,{ }^{* *} \mathrm{p}<0.01,{ }^{* * *} \mathrm{p}<0.001$. 